\title{
Environmental Quality and Preservation- Tiny Windows to Environmental Change: the Fascinating World of Microfossils
}

\begin{abstract}
Though small in size, calcareous (calcium carbonate) microfossils reveal volumes about geologic time, events, processes, and past climate. The U.S. Geological Survey (USGS) has the capability to provide significant scientific information based on microfossils that can be used to help resolve issues raised in many other disciplines. A source for pioneering investigations and new discoveries little recognized outside the field, microfossils and the stories they tell lie preserved in the geologic record.
\end{abstract}

\section{Introduction}

Microfossils are everywhere (Fig. 1). Generally the size of small sand grains, they are the fossilized remains of marine or terrestrial organisms. There are many kinds of microfossils ranging from terrestrial pollen spores to conodonts (toothlike fossil elements in form but not in function, produced by marine worms) to shells of calcareous marine organisms such as mollusks, pelecypods, ostracods, and foraminifera (forams). Nannofossils are extremely small calcareous marine microfossils not visible to the naked eye and include radiolarians and diatoms. Marine microfossils are important tools used to determine various aspects of the geologic and climatic record. In the modern world, some living faunas that become microfossils upon death are also used to measure changing marine conditions, including pollution. Pollution is generally considered a result of human activities, but other types of change such as variable salinity (salt content) or temperature of the water are more difficult to define as strictly natural or manmade. To help ascertain causes of these types of change, we must examine the geologic

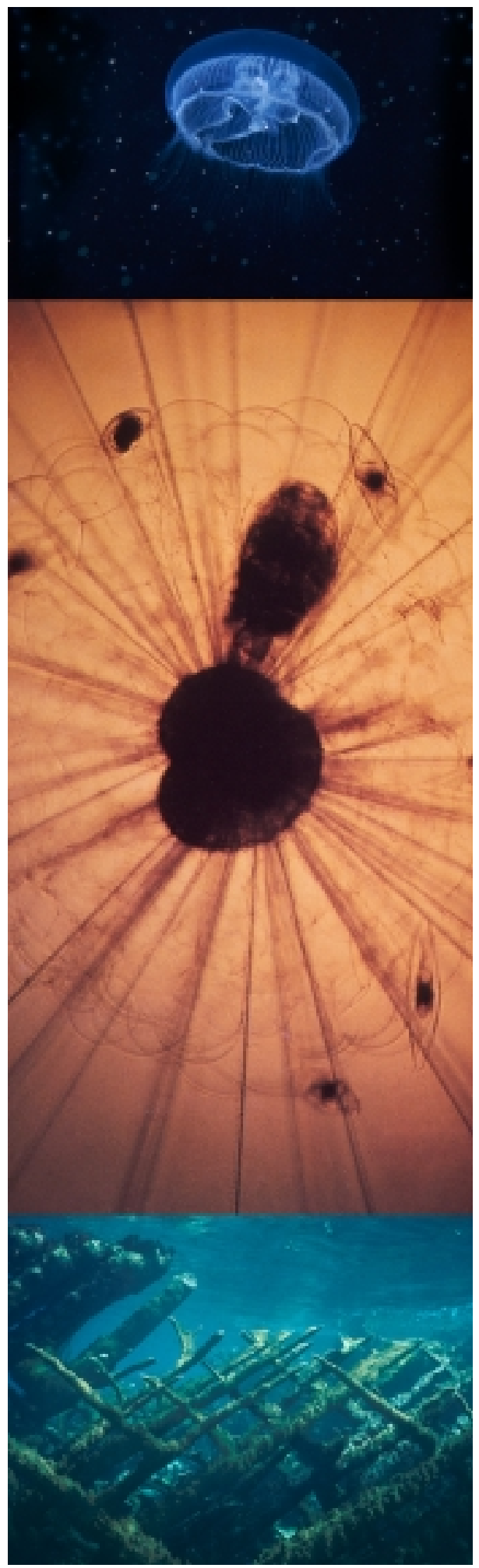

record, a record of natural processes and change.

One of the most common microfossil groups used in environmental studies is foraminifera. Forams are protozoans with external chambered shells. There are two types, planktic and benthic (Plate 1A, B). Both are distributed globally. Planktic (short for planktonic) forams are pelagic organisms that float as plankton in the open oceans. They live at various depths and construct their shells from elements dissolved in seawater. Species vary depending upon water depth, temperature, and latitude. An abundance of fossil pelagic species in deep-sea sediment indicates the overlying water was warm and nutrient-rich. Planktic species are relatively shortlived (a few million to tens of millions of years old) and are used to determine precise geologic age of the sediment or rock in which they are found, called host rock. Planktic forams reveal more than benthic forams about geologic time, processes, past environments and climates. Benthic forams are bottom dwellers. They live on or within the top layers of sediment from the shoreline to abyssal depths. Most also build their shells from elements dissolved in seawater, but some species use sand grains or other materials from their surroundings to construct their shells. Benthic forams are extremely long ranging (hundreds of millions of years old) and are seldom used for precise age dating. Instead, assemblages consisting of specific spe-

Figure 1. (top) Open-water floating plankton consists of organisms of all sizes. (center) Extruded-protoplasm bubbles around long thin spines on a planktic foram entrap other types of plankton for food. (bottom) Reefbuilding branching coral Acropora palmata and certain species of bottom-dwelling forams require similar conditions for survival. 


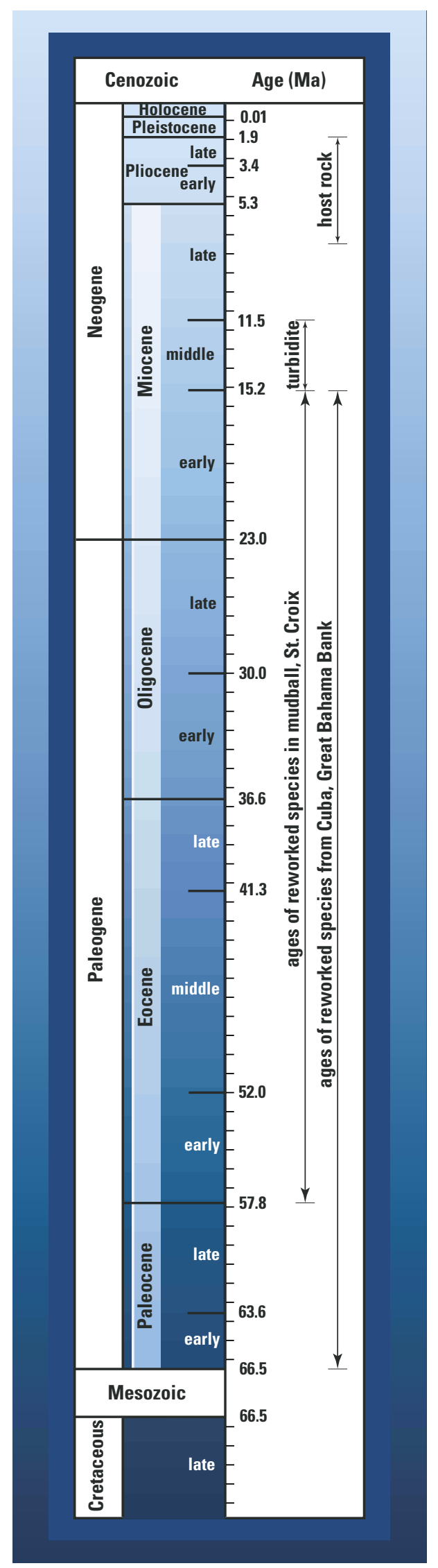

Figure 2. Geologic time scale showing Cenozoic epochs. Stratigraphic order occurs when sediments in a rock section progressively range from oldest at the bottom to youngest at the top, such as is observed in a core of undisturbed deep-sea sediments. $\mathrm{Ma}=$ million years. cies are used to indicate the general setting in which they lived (i.e., estuary, inner shelf, outer shelf, slope, and abyss), which implies a general water depth. In the geologic record of a tectonically stable area where there are no mountain-building processes, general water depth has implications for past position of sea level.

\section{The Field of Micropaleontology}

Micropaleontology is the study of microfossils. A micropaleontologist usually specializes in a single type of microfossil but is able to recognize organisms from other groups. A foraminiferal micropaleontologist uses forams along with other types of data from a sample site (for example, type of host rock or sediment, geographic setting, and seismic-survey data) to determine various attributes of the sample or group of samples. The attributes are then placed into the context of local geologic history-what happened at the site and when did it happen. Once 'what' and 'when' are resolved, the data can often be extrapolated into a larger picture - the regional or global record. For example, pollen spores from sediment cores are used to trace the presence and location of terrestrial plants and the movement of tree lines with changing climate through time. Conodonts become darker with age and thermal pressure through time and are used in the oil and gas industry as indicators of conditions favorable for hydrocarbon formation. When conodonts recovered from a certain subsurface depth within an exploratory well have attained a specific dark color, they verify that organics at that depth have reached the maturation stage to form oil and gas. Assuming that foram specimens are found in place, i.e., where they lived in the case of benthic species or where they fell to the ocean floor after death in the case of planktic species, the species are used to develop part of the local geologic record. Where floods, rivers, debris flows, and other processes have imported microfossils from somewhere else, the displaced or reworked faunas are used to tell something about the local site as well as possible distant sources and the types of processes that transported them. Regardless of specialty, given only the microfossils and little other solid evidence, a micropaleonologist is a forensic geologist who applies scientific knowledge and logical reasoning to interpret and reconstruct events of the past.

\section{Biostratigraphy}

Stratigraphy is the study of sedimentary or rock layers (strata) in the geologic (stratigraphic) record (Fig. 2). Layered strata are often observed in road cuts. A technique called seismic surveying is used to map subsurface strata. Seismic records or profiles show vertical slices through the ground that reveal the different layers. Biostratigraphy is the differentiation of rock layers based on distribution of the fossils they contain. The identifying fossils within each bed are to be found only in that particular portion of time when the bed was deposited (Winchester, 2001). Stratigraphic order represents the order through time in which the beds accumulated. Whether working with microfossils or dinosaurs, biostratigraphy is the primary method for determining ages of geologic events. Deep-sea biostratigraphy is the study of sediments and pelagic forams and nannofossils deposited in a deep-water environment. Identification of forams and nannofossils is also a key component in oil and gas exploration. Rock fragments containing microfossils are recovered from various intervals during drilling of a well. Fossils are identified and ages determined, and the depth interval of the sample is compared to seismic profiles and other types of data obtained in the area. Drilling continues until the fossils indicate that rock layers of an age known to contain hydrocarbons in the region are reached. Whether the new well will contain oil or gas depends on the structure of the hydrocarbon-bearing rocks and whether there is an impermeable layer or structural trap above them that would confine the oil or gas.

Deep-sea biostratigraphy is also used in settings that are no longer in 
deep water, such as at a shallow carbonate-platform margin to ascertain how and when the platform built seaward and the duration of expansion. The Great Bahama Bank in the Bahamas is an example of a carbonate platform. During high stands of sea level, carbonate platforms generally build seaward by shedding of shallow-water debris produced on the bank top. The process is called margin progradation. In tectonically active zones, biostratigraphy is used to tell the age of pelagic sediments now above sea level. Knowing the age of uplifted pelagic sediments can help determine the timing of processes, such as when tectonics occurred in the area or when volcanoes erupted. For instance, uplift took place after deposition of Cretaceous, Paleogene, and early Neogene (Fig. 2) pelagic forams and marls that now form mountains in northern Cuba. Volcanic-ash beds on St. Croix in the U.S. Virgin Islands are sandwiched between pelagic chalk layers that contain late Miocene foram species. If there are deep-sea marine sediments onshore in a tectonically stable area, age of the sediments as determined by the microfossils will denote a time when sea level was higher than today. Biostratigraphy of sediments from multiple cores in an area also enables correlation of the strata within the cores from which a cross section of the subsurface structure of the land can be developed.

\section{Planktic Forams: Indicators of Paleoclimates and Paleoenvironments}

Living planktic forams deposit in their shells different concentrations of carbon and oxygen isotopes and other minerals dissolved in seawater depending on water temperature and latitude.

Rapid changes in carbon-isotope concentrations in fossil planktic forams have been linked to sudden releases of frozen methane from the ocean floor, events that are thought to have caused periods of rapid global warming in the past. Though methane oxidizes to carbon dioxide, a greenhouse gas, atmospheric methane has 20 times the heat-trapping power of carbon dioxide. Variations in

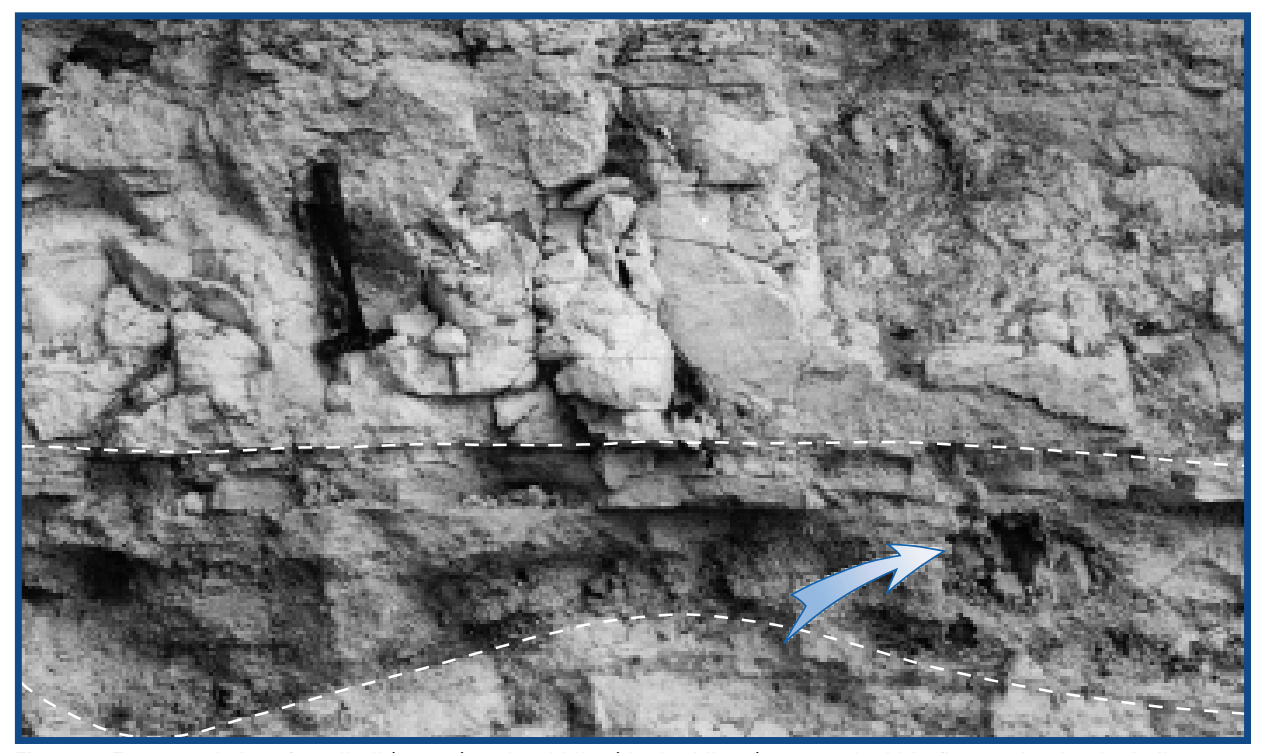

Figure 3. Excavated site of mudball (arrow) and turbidite (dashed lines) encased within fine-grained pelagic limestone on St. Croix. Turbidite layer is $\sim 0.5 \mathrm{~m}$ thick. Visible dimensions of mudball are $15 \times 25 \mathrm{~cm}$. Rock hammer for scale. $\mathrm{m}=$ meters. $\mathrm{cm}=$ centimeters.

oxygen-isotope concentrations in fossil species have also established ocean temperatures and temperature variations through time. The paleotemperature curve correlates with other data on climate change, such as glacial and interglacial intervals and corresponding data on sea-level changes. Planktic forams can develop abnormal shells as a response to environmental stress. Deformed shells of species living in the water column on the shelf off Newport Beach in Southern California have been linked to presence of offshore sewage outfalls. Many abnormal shells of fossilized species developed toward the end of the Miocene in waters over what is now St. Croix, probably in response to increasing Antarctic glaciation and associated cooling of the world's oceans. The youngest pelagic forams on the island, early Pliocene species, indicate the island emerged from the sea shortly after $\sim 5$ Ma (Fig. 2).

\section{Benthic Forams: Indicators of Stressed Environments and Pollution}

Living benthic forams are especially useful in detecting environmental perturbations. They have relatively short life cycles and specific habitats; thus, they tend to respond quickly to changes in their environments. They are diverse, abundant, easily sampled, and provide a cost-effective "bioindicator" that occurs in statistically significant numbers.
Benthic foram assemblages are becoming increasingly important as we learn more about the particular species that inhabit pristine waters, marginally polluted waters, or survive in heavily polluted areas. Some assemblages are known to be tolerant of variable and extreme conditions such as high or low salinity. In the fossil record, such assemblages could reflect a restricted shallow nearshore environment that was periodically impacted by high influx of freshwater runoff. Some species contain living algae when alive, as do species of the stony or reef-building corals. Stress symptoms in these species and in corals and coral reef communities are similar. Both types of organisms require clear ambient oceanic conditions. Both are now being affected in coral reef areas worldwide and are considered bioindicators of changing conditions. Like planktic forams, benthic forams also produce abnormal shells under stress. Pollution is a type of stress and often includes presence of heavy metals. Heavy metals can be incorporated into benthic foram shells as they grow. The type and concentration of metals in normal and abnormal parts of the shell can be detected through $\mathrm{x}$-ray analysis. The USGS in cooperation with the National Park Service is currently conducting investigations of the effects of pollutants on benthic forams in Biscayne Bay, Florida. The bay is the marine com- 

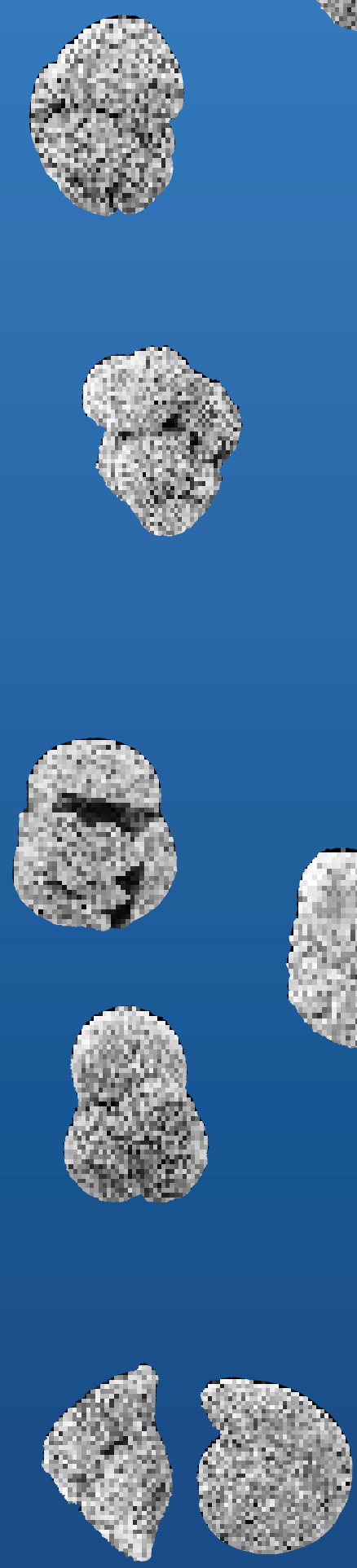
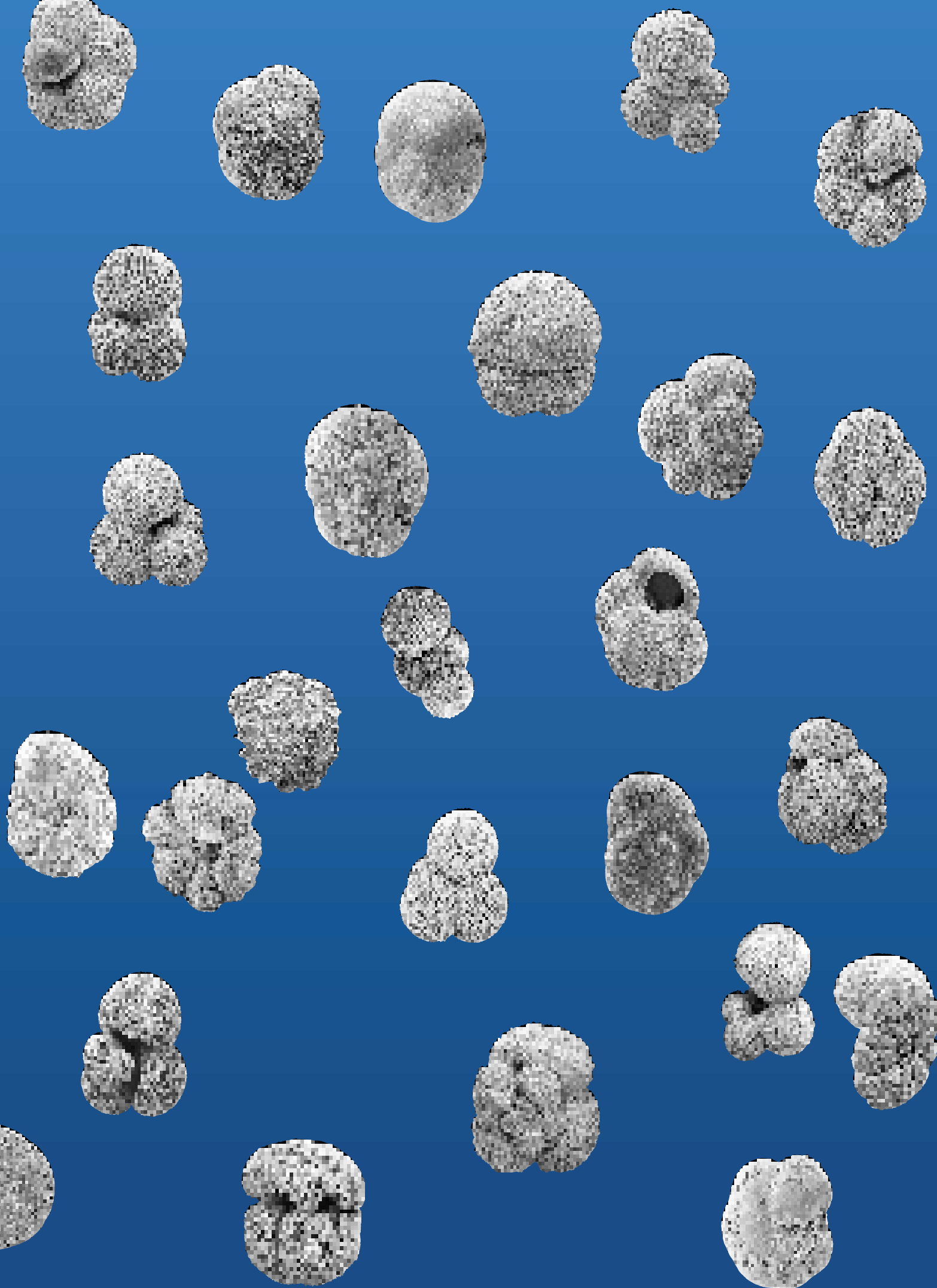

Plate 1. (A) Examples of planktic foraminifera. Shell shapes in many planktic species might be said to resemble popped popcorn. Shells of some species are essentially spherical. Others have elongate chambers and some have a single thick spine on each chamber. Other shells are conical, or flat like discs and have a peripheral keel. Shell shape, thickness, and other morphologic characteristics vary according to the water depth range in which the species primarily lives. In planktic species, shell morphology is linked to flotation. 


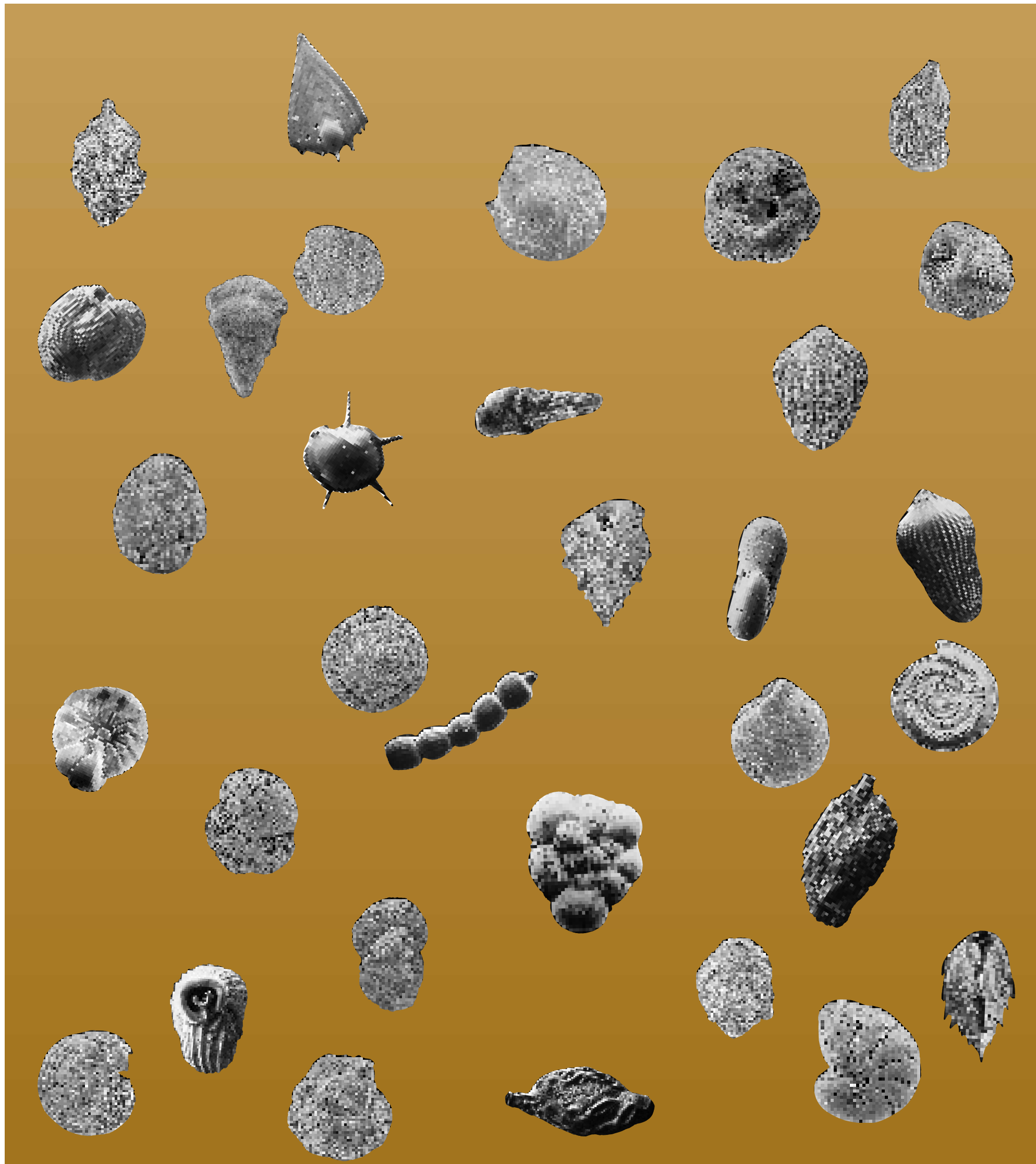

Plate 1. (B) Examples of benthic foraminifera. Shell shapes include flat, angular, tubular, branching, elongate, oval, and round. Some benthic species also have a single thick spine on each chamber. Depending on orientation, some species look like fans, tri-cornered hats, or single, double, or triple-scoop ice cream cones. Some species are encrusting and attach themselves to hard objects on the sea floor. Some burrow beneath the sediment surface. Some that live on grass blades are 'mobile' to the degree that they move up the blades toward sunlight. In benthic species, shell morphology is linked to seafloor setting and depth below sea level. 
ponent of Biscayne National Park. Abnormal benthic species found offshore may indicate that pollutants are reaching offshore waters. Benthic forams and geochemical analyses are complementary tools used for monitoring water quality in estuarine or coral reef settings.

\section{Significance of Reworked Microfossils: What Can They Reveal?}

The geologic record contains the only evidence anywhere for determining cause and effect of natural change. The microfossil part of the record can contain the potential and capacity to provide far more information than may at first be evident on the surface of a study.

\section{St. Croix, U.S. Virgin Islands}

The elongate island of St. Croix consists of volcanic rock at both ends separated by limestone that was deposited as layers of pelagic sediment in an ancient seaway prior to tectonic uplift. Depositional strata are revealed in road cuts throughout the seaway. In 1980, a specific hillside outcrop behind a private residence was free of vegetation and revealed a coarse-grained limestone layer encased in massive chalky deepwater limestone (Fig. 3). The coarsegrained layer, called a turbidite, had been deposited by a submarine debris flow. The turbidite contained a mudball inclusion consisting of homogenous clay. When analyzed for microfossils, the mudball yielded 39 species of reworked planktic forams (Fig. 2); 23 species had not previously been described from the island. The turbidite contained younger middle Miocene species. Though the mudball clay and the older fossils were the same ages, the mudball entity was middle Miocene because it was a part of the turbidite. The source of the mudball could not be determined, but the mudball demonstrates the existence relative to the submerged seaway floor of a steep submarine slope, probably of tectonic origin, that was composed of clay and was undergoing pelagic sedimentation between $\sim 57.8$ and 15.2 Ma. The mud- ball consistency and species composition also show that subsea reworking and mixing of fine-grained sediments were occurring at the mudball source at about 15.2 Ma. The turbidite-mudball package further documents submarine processes of large-scale sediment transport and admixing of dissimilar sedimentary bodies. Until the mudball was found, the oldest pelagic sediments identified on the island belonged to the early Miocene ( 23.0 Ma, Fig. 2). To this day, the mudball forams remain the only record known of earlier pelagic sedimentation in the area of St. Croix. The reworked microfossils had expanded the timeframe and depositional record of island-history knowledge by nearly 35 million years.

\section{Western Margin of the Great Bahama Bank, Bahamas}

Limestones in two long drill cores from the western margin of the Great Bahama Bank contain a particularly rich and enlightening record. The cores were obtained to verify ages of the host rock, inferred from seismic data to represent a complex depositional setting. The planktic microfossils revealed the magnitude of complexity. The setting itself posed a challenge for the foram/nannofossil part of the study: the cores were taken in shallow-water sediments in a shallowmargin setting that would normally preclude presence of deep-water faunas. But they were there, in abundance, especially in thin, condensed layers of strictly pelagic sediments. Presence of the pelagic microfossils and sediment layers demonstrated several facts. Water depth at the platform edge was once deep enough that planktic faunas lived there, sediment transport off the bank was intermittent, and the top of the platform was once farther inland and smaller than it is today. Critical first and last occurrences of marker species (those that indicate age) of both types of microfossils were out of stratigraphic order because of mixing by shallowwater debris shed from the platform. The host rock was eventually determined to range from $\sim 7.5$ to $1.9 \mathrm{Ma}$ (Fig. 2), but the planktic forams yielded far more information about the bank margin and the regional and global record than was ever imagined at the beginning of the study.

Besides host-rock faunas, the limestone contained abundant specimens of imported planktic forams that ranged from $\sim 66.5$ to $15.2 \mathrm{Ma}$ (Fig. 2). The 82 species identified were also uniquely deposited in the host rock. Paleocene, Eocene, Oligocene and early Miocene species were present in the bottoms of the cores. The middle parts of the cores contained Eocene, Oligocene and early Miocene faunas. Only Oligocene and early Miocene species were found near the core tops. In other words, the oldest displaced species were progressively and completely eliminated in successively younger intervals of host rock. Such an orderly distribution of reworked forams is unique to the geologic record in the Bahamas. Because of low-lying topography on the bank and very young host rock relative to ages of the reworked specimens, the displaced forams could not have been derived from elsewhere on the bank. This discovery led to a new direction of research, to determine their source.

The new direction required application of ancient regional geographic constraints, speed and direction of ancient currents, paleoclimatic data, and sealevel changes. The investigation required correlation of the original (source) and secondary (bank) depositional records of the reworked species with regional and global proxy data from studies by others. The reworked species represent pelagic deposition over 51 million years at their source. Their abundance indicates that the sediments in which they were originally deposited were easily eroded (i.e., not rock) millions of years later. Their unique redistribution in the cores implies tectonic forces at the source that produced a certain type of stratigraphically ordered submarine structure, then much later erosion of that structure by marine bottom currents over a period of $\sim 6$ million years (duration of accumulation in the host rock). Although 

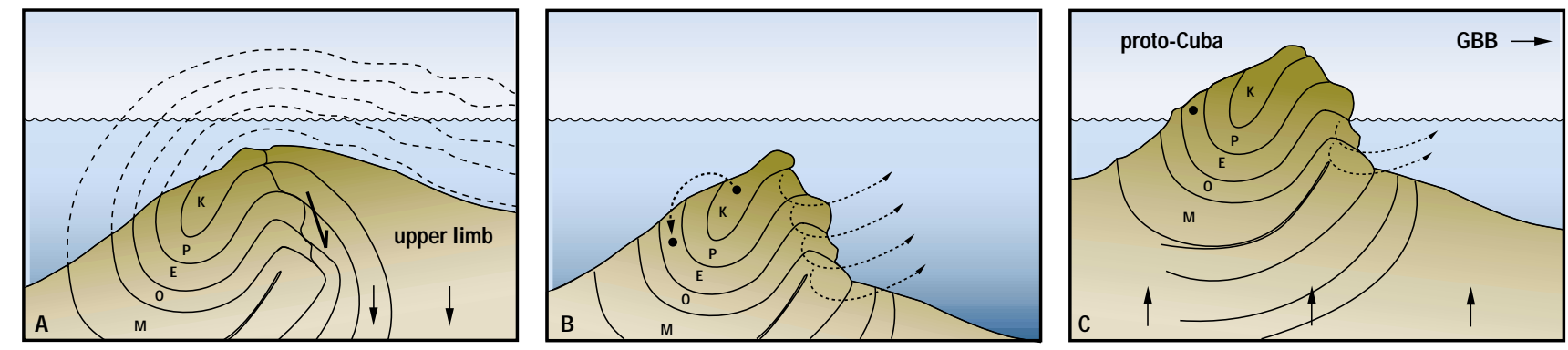

(A) Erosion (dashed lines), faulting, and subsidence of upper limb of overturned anticline expose stratigraphically reversed beds in low er limb. (B) Erosion of low er limb with slump block failure. (C) Uplift and emergence removes oldest sediments from erosional window. Note Cretaceous slump block (from $\mathrm{K}$ layer) in Eocene sediments. Diagram is based on actual stratification in uplifted mountain located $\sim 500 \mathrm{~m}$ from the shore near Bahia Nuevitas in northeast Cuba and $\sim 400 \mathrm{~km}$ from the western margin of the Great Baham Bank (GBB).
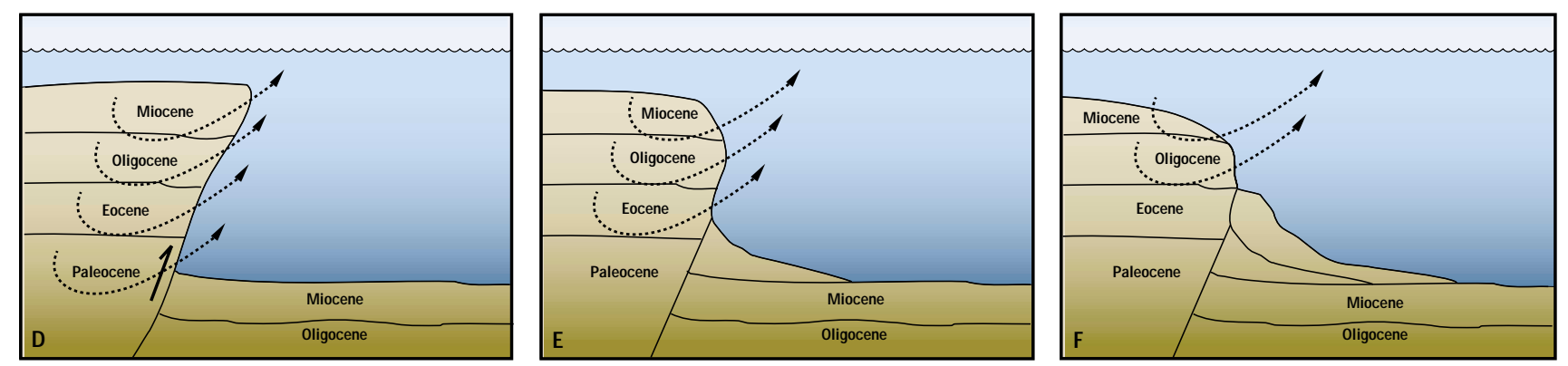

(D-F) Erosion of stratigraphically ordered thrust fault hanging w all with progressive burial of older strata by pelagic deposition or slumping.
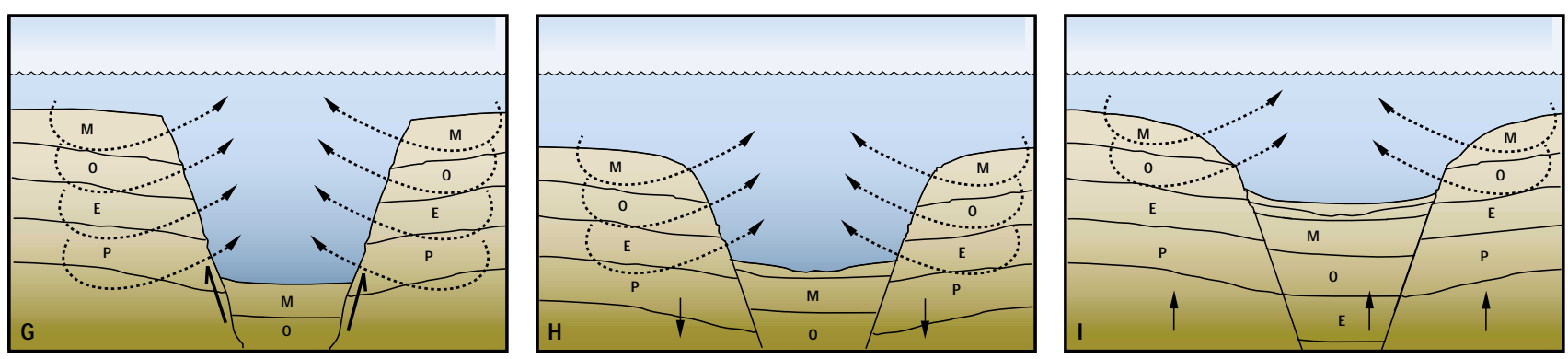

(G) Erosion of stratigraphically ordered faulted horst blocks. (H) Subsidence of fault blocks below zone of active erosion or below graben surface or burial by pelagic deposition or slumping removes oldest sediments from erosional window.

(I) Uplift of horst-and-graben system places horst blocks in less erosive shallow -marine setting.

Figure 4. Simplified structural models and generalized events characteristic of Cuban geology. The events could have produced the richly fossiliferous submarine source of pelagic foraminifera that were imported to the western margin of the Bahama Bank. Letters indicate epochs (stratigraphic ages) as shown in Figure 2. $\mathrm{K}=$ Cretaceous. $\mathrm{km}=$ kilometers. $\mathrm{m}=$ meters .

Florida is built of pelagic limestone of the same ages as the reworked species, the direction and velocity of the Gulf Stream, which was well established by the time of secondary deposition, eliminates Florida as the source. The only area in the Caribbean that meets all criteria for type and site of the source is located somewhere along the tectonically unstable northern coast of Cuba, some 400 to $700 \mathrm{~km}$ away from the western bank margin. The Cretaceous, Paleogene, and early Neogene pelagic forams now found in uplifted mountains along that coast are evidence. The only type of structure that could have been the source is a submarine wall with erodible strata either in stratigraphic or reverse stratigraphic order.

There are three possible models, all common tectonic structures. An eroded overturned anticline can exhibit layers in reversed stratigraphic order (Fig. 4A-C). Stratigraphically ordered layers can be found in a thrust fault hanging wall or a horst-and-graben system (Fig. 4D-I). Systematic redistribution of the forams at the bank margin represents systematic removal of layers containing the oldest species from the erosional window at the source, either by burial (submarine deposition) or by emergence of an eroded overturned anticline above sea level. Processes that occurred at the source include pelagic deposition, faulting, changing sea level, subsidence, erosion, and uplift and gradual emergence of Cuba. Lastly, using foraminiferal settling rates, size range of the reworked shells, and velocity, turbulence and direction of currents in channels 
between Cuba and the bank, remarkably short transit times were calculated for the imported specimens to reach the bank. Depending upon precise distance between the source on Cuba and the western bank margin, the reworked fossils could have made the trip in as many as 27 to 48 days or as few as 5 to 8 days.

The western margin of the Great Bahama Bank has long been believed to have built seaward solely through progradation. Yet through pelagic foraminifera, a new dimension and new depositional component are identified. The link between the bank and Cuba implies that the bank margin has advanced seaward primarily but not solely through progradation. Sediments from Cuba had to have been rafted along with the microfossils and therefore have helped build the margin. If it had not been for the microfossils, we would not have known that the young ( 7.5-1.9 Ma) host rock represents an approximately 6-millionyear-long time capsule. Through the window opened by the reworked species, we have a glimpse into, and a better understanding of, regional geologic processes and events and the global climatic record spanning nearly 66.5 million years of time.

\section{Summary}

The application of research involving living benthic forams is an increasingly important part of assessing changing conditions in the nearshore marine environment. The problem lies in determining whether the changes are natural, manmade, or both. The geologic record contains the only evidence anywhere for determining cause and effect of natural change. Earth-science studies that incorporate microfossils have a very high potential for leading to pioneering investigations and new discoveries. The study of microfossils can touch on many important questions and can benefit many other disciplines. Pelagic forams in particular are excellent and precise tools for a wide range of studies. Different types of microfossil data have

\section{Additional Reading:}

Ausich, W.I., 2000, Bones in the ivory tower: Geotimes, October, p. 18-21.

Cockey, E., Hallock, P., and Lidz, B., 1996, Decadal-scale changes in benthic foraminiferal assemblages off Key Largo, Florida: Coral Reefs, v. 15, p. 237-248.

Farley, M.B., and Armentrout, J.M., 2000, Fossils in the oil patch: Geotimes, October, p. 14-17.

Lidz, B.H., 1982, Biostratigraphy and paleoenvironment of Miocene-Pliocene hemipelagic limestone: Kingshill Seaway, St. Croix, U.S. Virgin Islands: Journal of Foraminiferal Research, v. 12, no. 3, p. 205-233.

Lidz, B.H., 1984, Oldest (early Tertiary) subsurface carbonate rocks of St. Croix, USVI, revealed in a turbidite-mudball: Journal of Foraminiferal Research, v. 14, no. 3, p. 213-227.

Lidz, B.H., 1984, Neogene sea-level change and emergence, St. Croix, Virgin Islands: Evidence from basinal carbonate accumulations: Geological Society of America Bulletin, v. 95, p. $1268-1279$.

Lidz, B.H., and McNeill, D.F., 1998, New allocyclic dimensions in a prograding carbonate bank: Evidence for eustatic, tectonic, and paleoceanographic control (Late Neogene, Bahamas): Journal of Sedimentary Research, v. 68, no. 2, p. 269-282.

Martin, R., 2000, The environmental stories of microfossils: A new research path for micropaleontology: Geotimes, January, p. 19-21.

Scott, D.B., and Lipps, J.H., 1995, eds., Environmental applications of foraminiferal studies: Journal of Foraminiferal Research, v. 25, no. 3, p. 189-286.

Winchester, S., 2001, The Map That Changed the World: William Smith and the Birth of Modern Geology: HarperCollins Publishers Inc., New York, 330 p.

\section{For more information, please contact:}

Barbara H. Lidz

U. S. Geological Survey

600 4th Street South

St. Petersburg, FL 33701

phone: 727-803-8747 x3031

fax: 727-803-2030

blidz@usgs.gov
This report is preliminary and has not been reviewed for conformity with U.S. Geological Survey editorial standards or with the North American Stratigraphic Code. Reference therein to any specific commercial product, process, or service by trade name, trademark, manufacturer, or otherwise does not necessarily constitute or imply its endorsement, recommendation, or favoring by the United States Government or any agency thereof. contributed to understanding past processes and climatic events that produced fluctuations in global sea level. The more we know about past climate and the causes that led to changes, the better we can predict what may trigger climate and sea-level change in the future.

The planktic foraminiferal record has unveiled remarkable evidence for heretofore-unknown sedimentary components and depositional complexity in a large carbonate bank. The reworked forams of the Great Bahama Bank are evidence of paleoceanographic, tectonic, and sea-level control on regional Cenozoic history. The quantity and diversity of the imported fossil faunas indicate that the global deep-sea record may be far more prevalent in uncommon settings or regions where it has not been sought than is presently realized. Microfossils provide fascinating information in ways that no other part of the geologic record can. 